\title{
Centro de Pesquisas Sociossemióticas: duas décadas de trabalho coletivo
}

Eric Landowski

Há vinte anos, o Centro de Pesquisas Sociossemióticas nasceu de um sonho. E, surpresa feliz, parece hoje que, em vez de desvanecer como tantos outros, esse sonho virou realidade... em parte pelo menos, e sob formas imprevistas, como era de prever. Vinte colóquios anuais! vinte cadernos de pesquisa! cinco coletâneas de livros, um número impressionante de dissertações e de teses, um conjunto de ateliers que durante todo esse tempo se renovaram sem parar, quatro convênios internacionais e vários interistitucionais com UNESP, UFES, UCPel. O Centro foi produtivo! E ele está agora mais vivo que nunca. Novos livros, outros eventos, projetos inéditos atestam-no. Vinte anos: le bel âge, portanto!

Mas, para melhor avaliar o percurso, lembremo-nos um instante de onde partimos. Em 1994, dois anos após a morte de Greimas, a semiótica estrutural encontrava-se em crise, sobretudo na França, onde toda a aventura tinha começado mais ou menos quarenta anos antes. Ademais, no contexto de uma Europa que acabava de entrar num interminável período de estagnação (não unicamente econômica), essa nossa semiótica, já um pouco envelhecida com seus modelos "canônicos", incansável e um tanto dogmaticamente utilizados e reutilizados como se fossem suficientes e, portanto, imutáveis, necessitava uma forma ou outra de superação.

Ao sonhar em transplantá-la para o outro lado do Atlântico, num país rico de uma imensa vitalidade e em pleno desenvolvimento como o Brasil, nossa espera, nossa meta, era impor à disciplina outro ritmo e ampliar seu alcance confrontando-a com um espaço cultural diferente. Com grande ambição, almejávamos abri-la sobre um conjunto de práticas e de preocupações decorrentes das transformações da sociedade brasileira em todos os seus níveis. Criar uma semiótica a serviço de uma reflexão societal e política! Isso, por definição, ultrapassava de longe o quadro das análises textuais, um tanto 
acadêmicas, às quais a maioria de nossos colegas europeus fazia questão de se limitar. Foi sob o impulso decisivo do trio araraquarense constituído pelos primeiros leitores brasileiros de Semântica estrutural — os mosqueteiros da semiótica neste país, Edward Lopes, Eduardo Peñuela Cañizal e Alceu Dias Lima - , que nos atrevemos a dar esse salto qualitativo. Daí o prefixo "sócio".

E daí, sobretudo, o estilo (sócio) semiótico deste nosso Centro então em gestação: um estilo que pouco a pouco iria fazer do "fazer semiótica" uma prática teórica e analítica deliberadamente comprometida com o ambiente, visando dar conta da experiência do sentido "em situação", quer dizer, na vida individual e coletiva tal como se articula em sociedades em mutação acelerada. Em outras palavras, uma semiótica "viva" — viva porque preocupada com o sentido "da vida". Mas, ao mesmo tempo, uma semiótica que devia ser tão rigorosa quanto possível, desde que se empenhasse em abordar níveis de reflexão e de análise ainda por consolidar ou construir: o sensível, a estesia, a dinâmica das interações vividas, a dialética dos regimes de sentido, etc. E ademais, uma semiótica legível, já que animada pelo desejo de sair do círculo auto-reprodutivo para interessar também os não-semioticistas — filósofos, sociólogos, administradores, jornalistas, arquitetos, artistas, entre outros.

A coordenação do programa de pós-graduação em Comunicação e Semiótica (COS) da PUC-SP, embora então de tendência peirciana, apoiou generosamente essa iniciativa e deu ao Centro uma localização institucional, sem interferir na linha teórica adotada por outro trio, aquele dos fundadores do Centro, Ana Claudia de Oliveira, José Luiz Fiorin e eu, o "professor importado". A essa linha inicial, permanecemos fiéis até hoje, e, oxalá, assim ficaremos. Pois, numa época de compromissos entre grupos, círculos, associações, federações e tutti quanti, é deste modo que, enquanto coletividade de pensamento, manteremos nossa identidade intelectual — ou será nossa marginalidade? — de "greimasianos", ou pós-greimasianos sem vergonha. "Fiéis", obviamente — é necessário precisá-lo? - , na infidelidade, pois, no caso, a verdadeira fidelidade exige a autocrítica, o diálogo e a inovação, isto é, uma constante transformação de si mesmos.

Como dizia o mestre Algirdas, il y a du pain sur la planche: "na tábua" sobra trabalho a fazer. Para mais dez anos, sem dúvida. - Dizer vinte seria, pessoalmente, por demais sonhar... Chegou o tempo de pensar em revezar a equipe! 